\title{
CORRELATION BETWEEN MATERNAL MID-UPPER ARM CIRCUMFERENCE AND ESTIMATED FETAL WEIGHT
}

\author{
Ratih Hermas Purnasari'1), Chichik Nirmasari'), Siti Haryani²) \\ ${ }^{1)}$ Study Program in Midwivery, Universitas Ngudi Waluyo, Ungaran, \\ Central Java, Indonesia \\ ${ }^{2)}$ Study Program in Nursing, Universitas Ngudi Waluyo, Ungaran, \\ Central Java, Indonesia
}

\begin{abstract}
Background: Maternal nutritional status, as estimated by anthropometrics, is an important contributor to fetal growth and infant birth weight. Therefore, simple and inexpensive anthropometric measurements, such as mid-upper arm circumference (MUAC), is used in large-scaled epidemiological studies to derive estimates of lean muscle mass and adiposity. In resource-limited settings, intrauterine growth assessments rely on serial fundal height measurements during antenatal care and determination of intrauterine growth restriction is based on low birth weight for estimated gestational age. This study aimed to investigate correlation between maternal MUAC and estimated fetal weight.
\end{abstract}

Subjects and Method: A cross-sectional study was carried out at Cemeng village, Sragen, Central Java. A number of 32 aterm pregnant women was selected for this study. The dependent variable was low estimated fetal weight. The independent variable was maternal mid-upper arm circumference (MUAC). Maternal MUAC was measured using standardized midline tape by Ministry of Health. Fetal weight was estimated by measuring uterine fundal height and calculated using Johnson formula. Correlation between maternal MUAC and fetal weight was analyzed by Chi square.

Results: Maternal MUAC $<23.5 \mathrm{~cm}$ increased the risk of low fetal weight $(<2,500 \mathrm{~g}) 13$ times than maternal MUAC $\geq 23.5 \mathrm{~cm}(\mathrm{OR}=13.13 ; 95 \% \mathrm{CI}=1.85$ to $92.96 ; \mathrm{p}=0.010)$.

Conclusion: Maternal MUAC $<23.5 \mathrm{~cm}$ increases the risk of low fetal weight.

Keywords: maternal mid-upper arm circumference, low fetal weight, pregnant women

\section{Correspondence:}

Ratih Hermas Purnasari. Study Program in Midwivery, Universitas Ngudi Waluyo Ungaran. Jl. Diponegoro 186, Ungaran, Semarang 50512, Central Java. Email: hermashp@gmail.com. Mobile: +6287700634677. 